\title{
Novel catalytic method synthesis of calix[4]pyrroles using Preyssler and Wells-Dawson heteropolyacids
}

\author{
Ali Gharib ${ }^{1,2 *}$, Manouchehr Jahangir ${ }^{1}$, J. (Hans) W. Scheeren ${ }^{3}$ \\ ${ }^{1}$ Department of Chemistry, Islamic Azad University, Mashhad, IRAN \\ ${ }^{2}$ Agricultural Researches and Services Center, Mashhad, IRAN \\ ${ }^{3}$ Cluster for Molecular Chemistry, Department of Organic Chemistry, Radboud University Nijmegen, The Netherlands \\ *Correspondence author: aligharib5@yahoo.com
}

\begin{abstract}
A catalytic synthesis of calix[4]pyrroles and $N$-confused calix[4]pyrroles by reaction of dialkyl or cycloalkyl ketones with pyrrole was performed using Preyssler, sodium30-tungsto pentaphosphate, $\left[\mathrm{NaP}_{5} \mathrm{~W}_{30} \mathrm{O}_{110}\right]^{14}$ and Wells-Dawson heteropolyacids as acidic catalysts. The process occurred under mild, eco-friendly and environmental friendly conditions and as a reusable, green catalyst at room temperature for 6 hours. The results showed that the yield for this synthesis is excellent with the use of Preyssler and Wells-Dawson type tungstophosphoric heteropolyacid, $\mathrm{H}_{6}\left[\mathrm{P}_{2} \mathrm{~W}_{18} \mathrm{O}_{62}\right]$, catalysts. The synthesis reaction of calix[4]pyrroles and $\mathrm{N}$-confused calix[4]pyrroles was developed using different solvents and the best yields were obtained in chloroform.
\end{abstract}

Keywords: Calix[4]pyrrole, Heteropolyacid, Preyssler, Wells-Dawson, Catalysis, $N$-confused calix[4]pyrrole.

\section{INTRODUCTION}

Heteropolyacids are classified according to their structures. Two classes, the Keggin and the Wells-Dawson structures, have been investigated more extensively than oth$\mathrm{ers}^{\mathbf{1}, \mathbf{2}}$. The use of heteropolyacids, HPAs, has recently received considerable attention as nontoxic, eco-friendly and environmentally benign catalysts for various organic transformations to afford the corresponding products in good yield. Due to the numerous advantages associated with these eco-friendly and green catalysts, HPAs and their salts have been explored as powerful, efficient and ecofriendly catalysts in organic reactions ${ }^{3}$. An important area of supramolecular chemistry is the design and synthesis of the receptors to recognize, sense and bind the anions $\mathbf{4}^{4}$. Calixarenes, a very important class of macrocyclic compounds which are widely used as ligands in supramolecular chemistry. Modification of the upper rim of calix[4]phenols by means of the $\mathrm{S}_{\mathrm{N}}{ }^{\mathrm{H}}$ coupling with electron-deficient triazinones is a new approach to change the molecular cavities of these compounds, which opens new possibilities for the construction of highly selective ligands ${ }^{5}$. The research and development have been made milder methods for the synthesis of porphyrins ${ }^{6}, \mathrm{~N}-\mathrm{C}$ isomerization ${ }^{7}$ and higher homologues of porphyrins ${ }^{8}$. The mesooctamethylcalix[4]pyrrole 3a has been prepared by condensation of pyrrole with acetone in the presence of aqueous hydrochloric acid or methanesulfonic acid in methanol9. Calix [4]pyrroles are conformationally flexible macrocycles ${ }^{10}$ of significant importance due to their binding under different conditions with anions ${ }^{11}$, neutral substrates $^{9}$ and metal ions ${ }^{12}$. The complexation behavior of calix[4]pyrroles with anions and cations has been widely studied using fluorescent ${ }^{13}$, colorimetric ${ }^{14}$ and electrochemical signaling ${ }^{15}$ devices. They find interesting applications as raw materials for transformation into novel calix[4]pyridines and calix[4]pyridinopyrroles ${ }^{\mathbf{1 6}}$, as new solid supports capable of separating anion mixtures ${ }^{16}$, in optical recognition of organic vapors ${ }^{17}$ and as biologically active species ${ }^{15}$. Porphyrinogens, bearing hydrogen atoms at meso positions, are key intermediates in biological and chemical synthesis of porphyrins ${ }^{18}$.

Synthesis of meso-octamethylcalix[4]pyrrole (3a) and the $N$-confused octamethylcalix[4]pyrrole (4b) using pyrrole and acetone in the presence of trifluoroacetic acid $^{19}$. The reactions of pyrrole with dialkyl ketones in the presence of protic acids $\left(\mathrm{HCl}, \mathrm{H}_{2} \mathrm{SO}_{4}\right)$, organic acids $\left(\mathrm{CH}_{3} \mathrm{SO}_{3} \mathrm{H}\right)$ and Lewis acids $\left(\mathrm{BBr}_{3}\right.$ and $\left.\mathrm{BF}_{3}\right)$ have also been used in the synthesis of calix[4]pyrroles ${ }^{20}$. The reaction of the excess of pyrrole with dialkylketones in the presence of acid gave 5,5-dialkyldipyrromethanes which in a subsequent reaction with dialkylketones in the presence of borontrifluoride-etherate formed strapped calix[4]pyrroles ${ }^{21}$. These acids are considered hazardous and corrosive and their removal from the reaction mixtures is difficult. Recently, condensations in dichloromethane of pyrrole with dialkyl ketones in the presence of the molecular sieve Al-MCM-41 and the zeolite $\mathrm{HY}$ afforded dipyrromethane, calix[4]pyrroles and other linear products, but not the $N$-confused calix[4]pyrroles ${ }^{22}$. Heteropolyacids (HPAs) is an inexpensive and non-hazardous solid acid, useful as a catalyst.

\section{EXPERIMENTAL SECTION}

\section{Chemicals and apparatus}

All chemical compounds were obtained from commercial sources and used as received.

The IR spectra were obtained with a Brucker 500 scientific spectrometer. ${ }^{1} \mathrm{H}$ NMR spectra were recorded in $\mathrm{CDCl}_{3}$ with TMS as internal standard on a FT NMR Bruker $100 \mathrm{MHz}$ Aspect 3000 spectrometer. The mass spectra were scanned on a Varian Mat. CH-7 at $70 \mathrm{ev}$. Melting points were recorded on an Electrothermal type 9100 melting point apparatus. 


\section{Preparation of Catalysts}

Preyssler catalyst, $\mathrm{H}_{14}\left[\mathrm{NaP}_{5} \mathrm{~W}_{30} \mathrm{O}_{110}\right]$, $\left(\mathrm{H}_{14}-\mathrm{P}_{5}\right)$

$\mathrm{H}_{14}-\mathrm{P}_{5}$ was prepared by a passage of a solution of the potassium salt in water through a column $(50 \mathrm{~cm} \times 1 \mathrm{~cm})$ of Dowex $50 \mathrm{~W} \times 8$ in the $\mathrm{H}^{+}$form and evaporation of the elute to dryness under vacuum ${ }^{\mathbf{2 3}}$.

Wells-Dawson species $\mathrm{H}_{6}\left[\mathrm{P}_{2} \mathrm{~W}_{18} \mathrm{O}_{62}\right]$

The Wells-Dawson species $\mathrm{H}_{6}\left[\mathrm{P}_{2} \mathrm{~W}_{18} \mathrm{O}_{62}\right]$ was prepared as described elsewhere ${ }^{24}$, from an aqueous solution of $\alpha / \beta \mathrm{K}_{6} \mathrm{P}_{2} \mathrm{~W}_{18} \mathrm{O}_{62} \cdot 10 \mathrm{H}_{2} \mathrm{O}$ salt, which was treated with ether and concentrated $(37 \%) \mathrm{HCl}$ solution.

\section{General procedure}

Preparation of calix[4]pyrroles (3a-g) and N-confused calix[4]pyrroles (4a-4e):

Synthesis of meso-octamethylcalix[4]pyrrole (3a) and $N$-confused octamethyl calix[4]-pyrrole (4a):

A mixture of pyrrole $(8 \mathrm{mmol})$, acetone $(8 \mathrm{mmol})$, $\mathrm{CHCl}_{3}(10 \mathrm{~mL})$ and heteropolyacids catalyst $(0.04 \mathrm{mmol})$ was added to the bottom flask, this mixture was stirred at room temperature for 6 hours. The reaction progress was monitored by thin layer chromatography (TLC). After the completion of the reaction, the catalyst was removed by filtration and washed thoroughly with $\mathrm{CHCl}_{3}$ to dissolve all the contents. The filtrate was concentrated to give the crude product, which was subjected to column chromatography to afford pure meso-octamethylcalix[4]pyrrole (3a). With further elution of the column with petroleum ether-chloroform $(2: 3, \mathrm{v} / \mathrm{v})$ gave the $N$-confused isomer of octametylcalix[4]pyrrole (4a). The above general method is used for the synthesis of different calix[4]pyrroles (3b-3g) and $N$-confused calix[4]pyrroles (4b, 4d and 4e).

\section{Reusability of catalyst}

The recycled catalyst could be washed with dichloromethane and subjected to a second run of the reaction process with the same substrate. The results of the first experiment and subsequent experiments were almost consistent in yields (83, 82.5 after three runs).

\section{Results and Discussion}

We wish to report the synthesis of calix[4]pyrrole (3a) and the $N$-confused calix[4]pyrrole (4a) use of heteropolyacids as acid catalyst, and we performed this synthesis in chloroform of pyrrole (1) with acetone for 6 hrs in the presence of Preyssler catalyst (Scheme 1, Table 1).

The results showed that the yield for this synthesis is excellent with the use of Preyssler and Wells-Dawson type tungstophosphoric heteropolyacid, $\mathrm{H}_{6}\left[\mathrm{P}_{2} \mathrm{~W}_{18} \mathrm{O}_{62}\right]$, catalysts. The synthesis reaction (Scheme 1) tested using different solvents and the best yields were obtained in chloroform (Table 2). We also considered the synthesis of calix[4]pyrrole (3a) by various heteropolyacids (Table 3 ).

We continued this synthesis with other ketones (2b-2g) and pyrrole in chloroform as a solvent and to use of Preyssler and Wells-Dawson type tungstophosphoric heteropolyacid, $\mathrm{H}_{6}\left[\mathrm{P}_{2} \mathrm{~W}_{18} \mathrm{O}_{62}\right]$, catalyst (Table 3).

The reactions of cycloheptanone (2f) and cyclooctanone (2g) with pyrrole and in the presence of Preyssler catalyst gave the corresponding calix[4]pyrroles (3f) and (3g) in

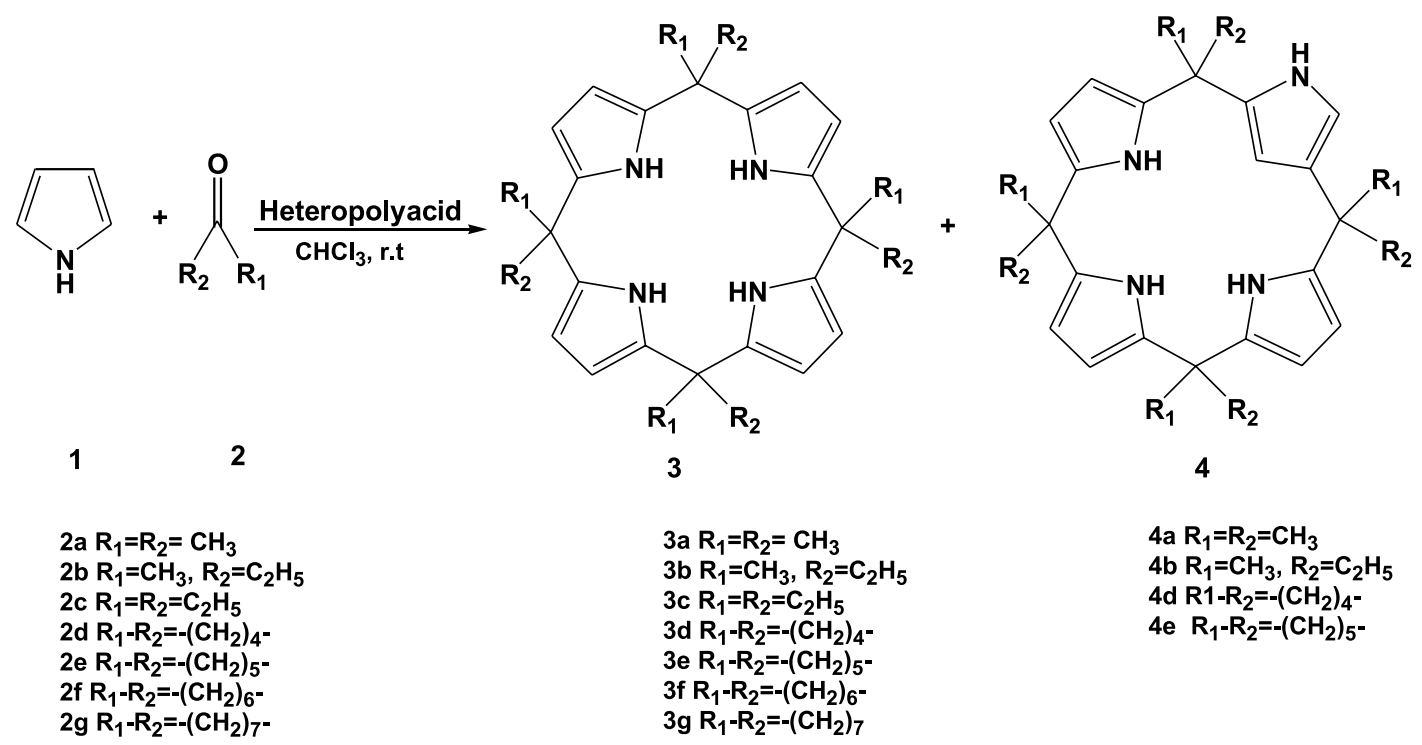

Scheme 1. Synthesis of Calix[4]Pyrroles using Preyssler and Wells-Dawson Heteropolyacids

Table 1. The reaction of different ketones $(2 \mathrm{a}-2 \mathrm{~g})$ with pyrrole in $\mathrm{CHCl}_{3}$, catalyzed by Preyssler heteropolyacid catalyst

\begin{tabular}{|c|c|c|c|c|c|c|}
\hline Compound & $\begin{array}{c}\text { Time } \\
\text { (h) }\end{array}$ & $\begin{array}{c}\% \\
\text { Conversion } \\
\text { of Pyrrole }\end{array}$ & ${ }^{\mathrm{a} Y i e l d}(\%) / \mathrm{mp}^{\circ} \mathrm{C},(3)$ & $\left(\right.$ lit.mp ${ }^{\circ} \mathrm{C},[$ ref.] $](3)$ & ${ }^{\mathrm{a} Y i e l d}(\%) / \mathrm{mp}^{\circ} \mathrm{C},(4)$ & $\left(\right.$ lit. $\mathrm{mp}{ }^{\circ} \mathrm{C}$, [ref.])(4) \\
\hline $2 a$ & 6 & 95 & $84.5 / 295$ & $(296[25])$ & $11.5 / 185$ & $(184-185[25])$ \\
\hline $2 b$ & 8 & 88 & $80 / 144$ & $(146[22])$ & $10 / 121$ & - \\
\hline $2 c$ & 18 & 71.5 & $74.5 / 222$ & - & - & - \\
\hline $2 d$ & 5 & 93 & $83 / 235$ & $(236[22])$ & $11.5 / 198$ & - \\
\hline $2 e$ & 5 & 96 & $85 / 273$ & $(271-272[25])$ & $12 / 224$ & $(223.2-223.6[25])$ \\
\hline $2 f$ & 24 & 37 & $32 / 163$ & - & - & - \\
\hline $2 g$ & 48 & 25.5 & $21.5 / 223$ & - & - & - \\
\hline
\end{tabular}

${ }^{a}$ Isolated yields. 
Table 2. Preyssler catalyzed condensation of pyrrole and acetone in different solvents

\begin{tabular}{|l|c|c|c|}
\hline Entry & Solvent & ${ }^{\mathrm{a}}$ Yield (\%) 3a & ${ }^{\mathrm{a}}$ Yield (\%) 4a \\
\hline 1 & $\mathrm{CHCl}_{3}$ & $84.5(83,82.5)^{\mathrm{b}}$ & $11.5(11,10.5)^{\mathrm{b}}$ \\
\hline 2 & $\mathrm{CCl}_{4}$ & 56 & - \\
\hline 3 & Benzene & 45 & - \\
\hline 4 & Toluene & 44 & - \\
\hline 5 & DMF & 39 & - \\
\hline 6 & DMSO & 36 & - \\
\hline 7 & Ethanol & 71.5 & 9.5 \\
\hline 8 & THF & 51 & - \\
\hline 9 & Acetonitril & 68 & 8 \\
\hline
\end{tabular}

${ }^{\mathrm{a}}$ Isolated yields. ${ }^{\mathrm{b}}$ Catalyst was reused over three runs. the presence of acid gave calix[4]pyrrole in preference to $\mathrm{N}$-confused calix[4]pyrrole ${ }^{25}$. The recovered catalyst was recycled twice with modest product yield loss being noted (Table 1). The catalytic activity of heteropolyacids catalysts are remarkable and it is environmentally benign. Heteropolyacids catalysts are commercially available. There are spectral data for compounds of $(\mathbf{3 a}-\mathbf{3 g}$ and $\mathbf{4 a}$, $\mathbf{4 b}, \mathbf{4 d}, \mathbf{4 e}$ ) in Tables 4, 5.

Table 3. The reaction of different ketones $(2 \mathrm{a}-2 \mathrm{~g})$ with pyrrole in $\mathrm{CHCl}_{3}$, catalyzed by Wells-Dawson and keggin (12tungestophosphoric acid)

\begin{tabular}{|c|c|c|c|c|c|}
\hline Compound & $\begin{array}{l}\text { Reaction time } \\
(\min )\end{array}$ & ${ }^{\mathrm{a}}$ Yield (\%) using $\mathrm{H}_{6} \mathrm{P}_{2} \mathrm{~W}_{18} \mathrm{O}_{62}(3)$ & $\begin{array}{l}{ }^{\text {a}} \text { Yield (\%) using } \\
\mathrm{H}_{3} \mathrm{PW}_{12} \mathrm{O}_{40} \text { (3) }\end{array}$ & ${ }^{\mathrm{a}}$ Yield (\%) using $\mathrm{H}_{6} \mathrm{P}_{2} \mathrm{~W}_{18} \mathrm{O}_{62}$ (4) & $\begin{array}{l}\text { aYield (\%) using } \\
\mathrm{H}_{3} \mathrm{PW}_{12} \mathrm{O}_{40}(4)\end{array}$ \\
\hline $2 a$ & 6 & 81 & 77 & 8.5 & 7 \\
\hline $2 b$ & 8 & 76.5 & 75 & 8 & - \\
\hline $2 c$ & 18 & 70 & 68 & - & - \\
\hline $2 d$ & 5 & 79 & 74.5 & 8 & - \\
\hline $2 e$ & 5 & 82.5 & 79 & 7.5 & - \\
\hline $2 f$ & 24 & 26 & 20 & - & - \\
\hline $2 g$ & 48 & 16.5 & 11.5 & - & - \\
\hline
\end{tabular}

${ }^{a}$ Isolated yields.

$32 \%$ and $21.5 \%$ yield at ambient temperature, but the time required for the conversions was considered too long. In the reactions of pyrrole with $\mathbf{2 c}, \mathbf{2 f}$ and $\mathbf{2 g}$, the corresponding $N$-confused calix[4]pyrroles could not be isolated. This could be attributed to the steric hindrance encountered with these higher acyclic and cyclic ketones. The C-2 and C-5 atoms are more reactive than the C-3 and $\mathrm{C}-4$ positions in pyrrole, hence the electrophilic reaction at $\mathrm{C}-2$ and $\mathrm{C}-5$ position of pyrrole with acetone in

\section{CONCLUSIONS}

We reported a catalytic method for synthesis of calix[4]pyrrole using Preyssler and heteropolyacids catalysts as an efficient, reusable and eco-friendly heterogeneous inorganic catalyst. It is noteworthy to mention that the catalyst is reusable. Even after three runs for the calix[4]pyrrole reaction, the catalytic activity of $\mathrm{H}_{14}\left[\mathrm{NaP}_{5} \mathrm{~W}_{30} \mathrm{O}_{110}\right]$ was almost the same as that of the

Table 4. ${ }^{1} \mathrm{H}$ NMR spectral data for meso-octaalkyl and cycloalkyl calix[4]pyrroles 3a-3g

\begin{tabular}{|l|l|}
\hline Compound & ${ }^{1} \mathrm{HNMR} \delta(\mathrm{ppm})^{\mathrm{a}}$ \\
\hline 3a & $7.01(4 \mathrm{H}, \mathrm{br} \mathrm{s}, \mathrm{NH}), 5.89(8 \mathrm{H}, \mathrm{d}, \mathrm{J}=2.5 \mathrm{~Hz}, \beta$-pyrrole), 1.50 $(24 \mathrm{H}, \mathrm{s})$ \\
\hline 3b & $\begin{array}{l}6.97(4 \mathrm{H}, \mathrm{br} \mathrm{s}, \mathrm{NH}), 5.80(8 \mathrm{H}, \mathrm{d}, \mathrm{J}=2.5 \mathrm{~Hz}, \beta \text {-pyrrole }), 1.79-1.76\left(8 \mathrm{H}, \mathrm{q},-\mathrm{CH}_{2}\right), 1.45-1.18\left(12 \mathrm{H}, \mathrm{br} \mathrm{s}, \mathrm{CH}_{3}\right), 0.80-0.63(12 \mathrm{H}, \mathrm{t}, \\
\left.\mathrm{CH}_{3}\right)\end{array}$ \\
\hline 3c & $7.05(4 \mathrm{H}, \mathrm{br} \mathrm{s}, \mathrm{NH}), 5.89\left(8 \mathrm{H}, \mathrm{d}, \mathrm{J}=2.3 \mathrm{~Hz}, \beta\right.$-pyrrole), 1.79-1.57 $\left(16 \mathrm{H}, \mathrm{q},-\mathrm{CH}_{2}\right), 0.71-0.58\left(24 \mathrm{H}, \mathrm{t}, \mathrm{CH}_{3}\right)$ \\
\hline 3d & $7.03(4 \mathrm{H}, \mathrm{br} \mathrm{s}, \mathrm{NH}), 5.85(8 \mathrm{H}, \mathrm{d}, \mathrm{J}=2.3 \mathrm{~Hz}, \beta$-pyrrole $), 2.21-2.00(16 \mathrm{H}, \mathrm{m}), 1.68-1.44(16 \mathrm{H}, \mathrm{m})$ \\
\hline 3e & $7.25(4 \mathrm{H}, \mathrm{br} \mathrm{s}, \mathrm{NH}), 5.89(8 \mathrm{H}, \mathrm{d}, \mathrm{J}=2.5 \mathrm{~Hz}, \beta$-pyrrole), 1.91-1.90 $(16 \mathrm{H}, \mathrm{m}), 1.50-1.41(24 \mathrm{H}, \mathrm{m})$ \\
\hline 3f & $6.88(4 \mathrm{H}, \mathrm{br} \mathrm{s}, \mathrm{NH}), 5.83(8 \mathrm{H}, \mathrm{d}, \mathrm{J}=2.5 \mathrm{~Hz}, \beta$-pyrrole), 2.01-1.94 $(16 \mathrm{H}, \mathrm{m}), 1.72-1.52(32 \mathrm{H}, \mathrm{m})$ \\
\hline 3g & $6.99(4 \mathrm{H}, \mathrm{br} \mathrm{s}, \mathrm{NH}), 5.93(8 \mathrm{H}, \mathrm{d}, \mathrm{J}=2.4 \mathrm{~Hz}, \beta$-pyrrole), 1.97-1.95 $(16 \mathrm{H}, \mathrm{m}), 1.52-1.34(32 \mathrm{H}, \mathrm{m}), 1.23-1.21(8 \mathrm{H}, \mathrm{m})$ \\
\hline
\end{tabular}

${ }^{a}$ All products are known, characterized by ${ }^{1} \mathrm{H}-\mathrm{NMR}$ and compared with authentic samples [22].

Table 5. ${ }^{1} \mathrm{H}$ NMR spectral data for meso-octaalkyl and cycloalkyl $N$-confused calix[4]pyrroles $4 \mathrm{a}, 4 \mathrm{~b}, 4 \mathrm{~d}, 4 \mathrm{e}$

\begin{tabular}{|c|c|}
\hline Compound & ${ }^{1} \mathrm{HNMR} \delta(\mathrm{ppm})$ \\
\hline a $4 a$ & $\begin{array}{l}\mathrm{NH}: 7.75(1 \mathrm{H}, \mathrm{br}), 7.41(1 \mathrm{H}, \mathrm{br}), 7.26(2 \mathrm{H}, \mathrm{br}) ; \alpha \text {-pyrrole: } 6.30(1 \mathrm{H}, \mathrm{d}, J=2 \mathrm{~Hz}), \beta \text {-pyrrole: } 6.04(2 \mathrm{H}, \mathrm{br}), 5.97(2 \mathrm{H}, \mathrm{br}), 5.93(2 \mathrm{H} \text {, } \\
\mathrm{m}), 5.50(1 \mathrm{H}, \mathrm{br}) ; 1.56-1.48(24 \mathrm{H}, \mathrm{m})\end{array}$ \\
\hline 4b & $\begin{array}{l}\mathrm{NH}: 7.63(1 \mathrm{H}, \mathrm{br}), 7.53(1 \mathrm{H}, \mathrm{br}), 7.35(2 \mathrm{H}, \mathrm{br}) ; \alpha \text {-pyrrole: } 6.40(1 \mathrm{H}, \mathrm{d}, \mathrm{J}=2 \mathrm{~Hz}) ; \beta \text {-pyrrole: } 6.03(2 \mathrm{H}, \mathrm{br}), 5.88(2 \mathrm{H}, \mathrm{br}), 5.78(2 \mathrm{H} \text {, } \\
\text { m), } 5.53(1 \mathrm{H}, \mathrm{br}) ; 1.92\left(3 \mathrm{H}, \mathrm{s}, \mathrm{CH}_{3}\right), 1.83-1.12(29 \mathrm{H}, \mathrm{m})\end{array}$ \\
\hline 4d & $\begin{array}{l}\mathrm{NH}: 7.48(1 \mathrm{H}, \mathrm{br}), 7.29(1 \mathrm{H}, \mathrm{br}), 7.00(2 \mathrm{H}, \mathrm{br}) ; \alpha \text {-pyrrole: } 6.42(1 \mathrm{H}, \mathrm{d}, \mathrm{J}=1.97 \mathrm{~Hz}) ; \beta \text {-pyrrole: } 6.00(2 \mathrm{H}, \mathrm{br}), 5.90(2 \mathrm{H}, \mathrm{br}), 5.88 \\
(2 \mathrm{H}, \mathrm{m}), 5.58(1 \mathrm{H}, \mathrm{br}) ; 2.25-1.98(16 \mathrm{H}, \mathrm{m}), 1.50-1.20(16 \mathrm{H}, \mathrm{m})\end{array}$ \\
\hline a $4 e$ & $\begin{array}{l}\mathrm{NH}: 7.63(1 \mathrm{H}, \mathrm{br}), 7.44(1 \mathrm{H}, \mathrm{br}), 7.10(2 \mathrm{H}, \mathrm{br}) ; \alpha-\text { pyrrole: } 6.42(1 \mathrm{H}, \mathrm{d}, J=1.98 \mathrm{~Hz}) ; \beta \text {-pyrrole: } 6.03(2 \mathrm{H}, \mathrm{br}), 5.97(2 \mathrm{H}, \mathrm{br}), 5.82 \\
(2 \mathrm{H}, \mathrm{m}), 5.50(1 \mathrm{H}, \mathrm{br}) ; 2.70-2.10(16 \mathrm{H}, \mathrm{m}), 1.60-1.20(24 \mathrm{H}, \mathrm{m})\end{array}$ \\
\hline
\end{tabular}

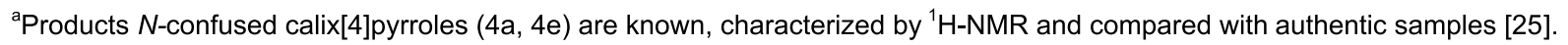


freshly used catalyst. $\mathrm{H}_{14}\left[\mathrm{NaP}_{5} \mathrm{~W}_{30} \mathrm{O}_{110}\right]$ is non-corrosive and environmentally benign and presents fewer disposal problems.

\section{Acknowledgments}

The authors are thankful to Agricultural Researches \& Services Center, Mashhad, Feyzabad, Iran and Mashhad Islamic Azad University and Chemistry Department, University of Oslo, Norway and National Research Council Canada for support of this work and with special thanks to Professor Dr. J. (Hans) W. Scheeren from Organic Chemistry Department, Radboud University Nijmegen, The Netherlands.

\section{LITERATURE CITED}

1. Kozhevnikov, I.V. (1998). Catalysis by Heteropoly Acids and Multicomponent Polyoxometalates in LiquidPhase Reactions. Chem. Rev. 98, 171-198. DOI: 10.1021/ cr960400y.

2. Izumi, Y., Urabe, K. \& Onaka, M. (1992). Zeolite, Clay and Heteropoly Acid in Organic Reactions, Kodansha/VCH, Tokyo.

3. Okuhara, T., Mizuno., N. \& Misono, M. (1996). Catalytic Chemistry of Heteropoly compounds, Advances in Catalysis. 41, 113-252.

4. Gale, P.A., Sessler, J.L. \& Král, V. (1998). Calixpyrroles. Chem. Commun. 1-8. DOI: 10.1039/ A706280J.

5. Chupakhin, O.N., Rusinov, G.L., Itsikson, N.A., Beresnev, D.N. \& Kodess, M.I. (2003). Abstracts of the First World Congress on Synthetic Receptors, Lisbon. p. 2.01 .

6. Chauhan, S.M.S., Sahoo, B.B. \& Sriniwas, K.A. (2001). Microwave assisted synthesis of 5,10,15,20tetraarylporphyrins. Synth. Commun. 31, 33-37. DOI: 10.1081/SCC-100000176.

7. Geier, G.R., Haynes, D.M. \& Lindsey, J.S. (1999). An efficient one-flask synthesis of $N$-confused tetraphenylporphyrin. Org. Lett. 1455-1458. DOI: 10.1021/ol9910114.

8. Chandrashekar, T.K. \& Venkatraman, S. (2003). Coremodified expanded porphyrins: new generation organic materials. Acc. Chem. Res. 36, 676-691. DOI: 10.1021/ $\operatorname{ar} 020284 \mathrm{n}$.

9. Rothenmund, P. \& Gage, V. (1955). Concerning the structure of acetonepyrrole. J. Am. Chem. Soc. 77, 33403341. DOI: $10.1021 / \mathrm{ja} 00117 \mathrm{a} 004$.

10. Sessler, J.L., Camiolo, S. \& Gale, P.A. (2003). Pyrrolic and polypyrrolic anion binding agents. Coord. Chem. Rev. 240, 17-55. DOI: 10.1016/S00108545(03)00023-7.

11. Gale, P.A., Sessler, J.L., Král, V. \& Lynch, V.J. (1996). Calix[4]pyrroles: Old yet new anion-binding agents. J. Am. Chem. Soc. 118, 5140-5141. DOI: 10.1021/ ja960307r.

12. Bachmann, J. \& Nocera, D.G. (2005). Multielectron redox chemistry of iron porphyrinogens. J. Am. Chem. Soc. 127, 4730-4743. DOI: 10.1021/ja043132r.

13. Miyaji, H., Anzenbacher, P., Sessler, J.L., Bleasdale, E.R. \& Gale, P.A. (1999). Anthracene-linked calix[4]pyrroles: fluorescent chemosensors for anions. Chem. Commun. 1723-1724. DOI: 10.1039/A905054J.
14. Gale, P.A., Twyman, L.J., Handlin, C.I., Sessler, J.L. (1999). A colourimetric calix[4]pyrrole-4-nitrophenolate based anion sensor. Chem. Commun. 1851-1852. DOI: 10.1039/A905743I.

15. Gale, P.A., Hursthouse, M.B., Light, M.E., Sessler, J.L., Warriner, C.N. \& Zimmerman, R.S. (2001). Ferrocene-substituted calix[4]pyrrole: a new electrochemical sensor for anions involving $\mathrm{CH}$ anion hydrogen bonds. Tetrahedron Lett. 42, 6759-6762. DOI: 10.1016/S0040-4039(01)01337-5.

16. Král, V., Gale, P.A., Anzenbacher, Jr.P., Jursíková, K., Lynch, V. \& Sessler, J.L. (1998). Calix[4]pyridine: a new arrival in the heterocalixarene family. Chem. Commun. 9-10. DOI: 10.1039/A706018A.

17. Conoci, S., Palumbo, M., Pignataro, B., Rella, R., Valli, L. \& Vasapollo, G. (2002). Optical recognition of organic vapors through ultra thin calix[4]pyrrole films. Colloid. Surf. A: Physicochem. Eng. Asp. 198, 869-873. DOI: 10.1016/S0927-7757(01)01013-5.

18. Floriani, C. (1996). The porphyrinogen-porphyrin relationship: the discovery of artificial porphyrins. Chem. Commun. 1257-1263. DOI: 10.1039/CC9960001257.

19. Depraetere, S., Smet, M. \& Dehaen, W. (1999). $N$-confused calix[4]pyrroles. Angew. Chem. Int. Ed. 38, 3359-3361. DOI: 10.1002/(SICI)1521-3773(19991115) 38:22<3359::AID-ANIE3359>3.0.CO;2-K.

20. Anzenbacher, Jr.P., Jursíková, K., Lynch, V.M., Gale, P.A. \& Sessler, J.L. (1999). Calix[4]pyrroles containing deep cavities and fixed walls. Synthesis, structural studies, and anion binding properties of the isomeric products derived from the condensation of p-hydroxyacetophenone and Pyrrole. J. Am. Chem. Soc. 121, 11020-11021. DOI: 10.1021/ja993195n.

21. Miyaji, H., Hong, S., Jeong, D., Yoon, D., Na, H., Hong, J., Ham, S., Sesseler, J.L. \& Lee, C.A. (2007). A Binol-Strapped Calix[4]pyrrole as a Model Chirogenic Receptor for the Enantioselective Recognition of Carboxylate Anions. Angew. Chem. Int. Ed. 46, 2508-2511. DOI: $10.1002 /$ anie.200604161.

22. Radha Kishan, M., Srinivas, N., Raghavan, K.V.,. Kulkarni, S.J. \& Sarma, J.A.R.P. (2001). A novel, shapeselective, zeolite-catalyzed synthesis of calix[4]pyrroles. Chem. Commun. 2226-2227. DOI: 10.1039/B105690P.

23. Bamoharram, F.F., Heravi, M.M., Roshani, M., Jahangir, M. \& Gharib, A. (2006). Preyssler catalyst, $\left[\mathrm{NaP}_{5} \mathrm{~W}_{30} \mathrm{O}_{110}\right]^{14-}$ : A green, efficient and reusable catalyst for esterification of salicylic acid with aliphatic and benzylic alcohols. Applied Catalysis A: General. 302, 42-47. DOI: $10.1016 /$ j.apcata.2005.12.021.

24. Romanelli, G., Autino, J.C., Baronetti, G. \& Thomas, H. (2001). H. Efficient Deprotection of Phenol Methoxymethyl Ethers Using a Solid Acid Catalyst with Wells-Dawson Structure. Molecules. 6, 1006-1011. DOI: 10.3390/61201006.

25. Anzenbacher, Jr.P., Nishibayu, R. \& Palacios, M.A. (2006). N-confused calix[4]pyrrole. Coord. Chem. Rev. 250, 2929-2938. DOI: 10.1016/j.ccr.2006.09.001. 